\title{
Post-Learning Cycle, a Web-Based Formative Assessment Model on Physics Learning Temperature and Heat Matter
}

\author{
Ediyanto $^{\text {a, * }}$ \\ ${ }^{a}$ Universitas Yudharta Pasuruan \\ *E-mail: ediyanto@yudharta.ac.id
}

\begin{abstract}
Web-based formative assessment model in the current study divided into three cycles of a prelearning cycle, learning cycle, and post-learning cycle. Previous research in the pre-learning stage, web-based formative assessment models can provide feedback quickly and can improve students' understanding of concepts. The current study develops the post-learning cycle, a web-based formative assessment model in physics specifically for heat and temperature materials in vocational school students grade $\mathrm{X}$. The present study is used in the research and development method. Post-learning cycle, a web-based formative assessment model developed with six stages: 1) the collection of information and drafting, 2) planning, 3) establish initial product, 4) validate the initial product, 5) revisions, and 6) trial in the field. As a result, the post-learning cycle, a WebBased formative assessment model is divided into three stages: diagnostic test, recording, and feedback. Based on trial results, it was found that the post-learning cycle, a web-based formative assessment model can help teachers and students to get quick feedback. Rapid feedback can help students to gain an understanding of the concept quickly and can help teachers to find students so that problems can be solved promptly. This formative assessment model can be used as a tool for assessment and evaluation of the achievement of student learning outcomes. In the future, a postlearning cycle, a Web-Based formative assessment model, can be used for learning other than physics.
\end{abstract}

Keywords: Formative Assessment, Feedback, Physics Learning, Web-based.

\section{Introduction}

Formative assessment can provide feedback to teachers (Arifin, 2009) and students (Fakcharoenphol, Potter, \& Stelzer, 2011; Etkina, 2002) as a basis for improving the learning process and conducting remedial programs for students in education. Formative assessment is most appropriate because the assessment process involves students directly in the learning process 
(Arends, 2008; Arifin, 2009; McAlpine, 2002) and can help students to gain an understanding of concepts (Irons, 2008; Arifin, 2009; Stull, Varnum \& Ducette, 2011).

The feedback contained in formative assessment in learning will involve students both individually and in groups, so that knowledge can further increase interest and enthusiasm in education (Subroto, 2010). Feedback can be an alternative solution for students who do not understand the concept (Stull, Varnum \& Ducette, 2011; Lipnevich \& Smith, 2009). Formative assessment can be carried out in two ways, namely when learning or outside learning (Otsuka \& Vieira da Rocha, 2007; Wagner \& Vaterlaus, 2011). The implementation of formative assessment outside of learning is done online, which is usually done on a distance learning system. Formative assessment is carried out when learning takes place that is by question and answer, clicker, observation, quizzes, and tests.

Based on the pre-learning cycle, a web-based formative assessment model can help teachers and students get quick feedback. The pre-learning cycle has the goal of enabling students to know the range of materials that teachers will be taught and to know the mistakes of the initial concept of the content to be explained by the teacher. For teachers, this cycle aims to see students' early skills and can design lessons with an emphasis on the most dominant student misconceptions (Ediyanto, 2016). The advantage of this cycle is that teachers and students get feedback quickly (Ediyanto, 2016).

The web-based formative assessment model divided into three cycles. They are the pre-learning cycle, on the learning cycle, and the post-learning cycle (Ediyanto, 2014), as shown in Figure 1. The pre-learning cycle implemented before the learning begins. The learning cycle was conducted during the learning process. Then, the post-learning cycle applied after learning. The pre-learning cycle and post-learning cycle were done online out of hours learning while learning cycles performed offline and also online when learning takes place. The media used in the valuation model are Moodle. This research developed a post-learning cycle, a web-based formative assessment model in physics and heat temperature materials for vocational students class $\mathrm{X}$.

\section{Method}

The current study is used as a research and development method. The post-learning cycle, a web-based formative assessment model, developed with six stages. The steps of research and development by Borg and Gall (1983: 775) and adapted to this development research. Based on the development model, set the model development for the post-learning cycle, a web-based formative assessment model is a) gathering information and drafting, b) planning, c) developing an initial product, d) validating, e) revision, and f) trial in the field. 


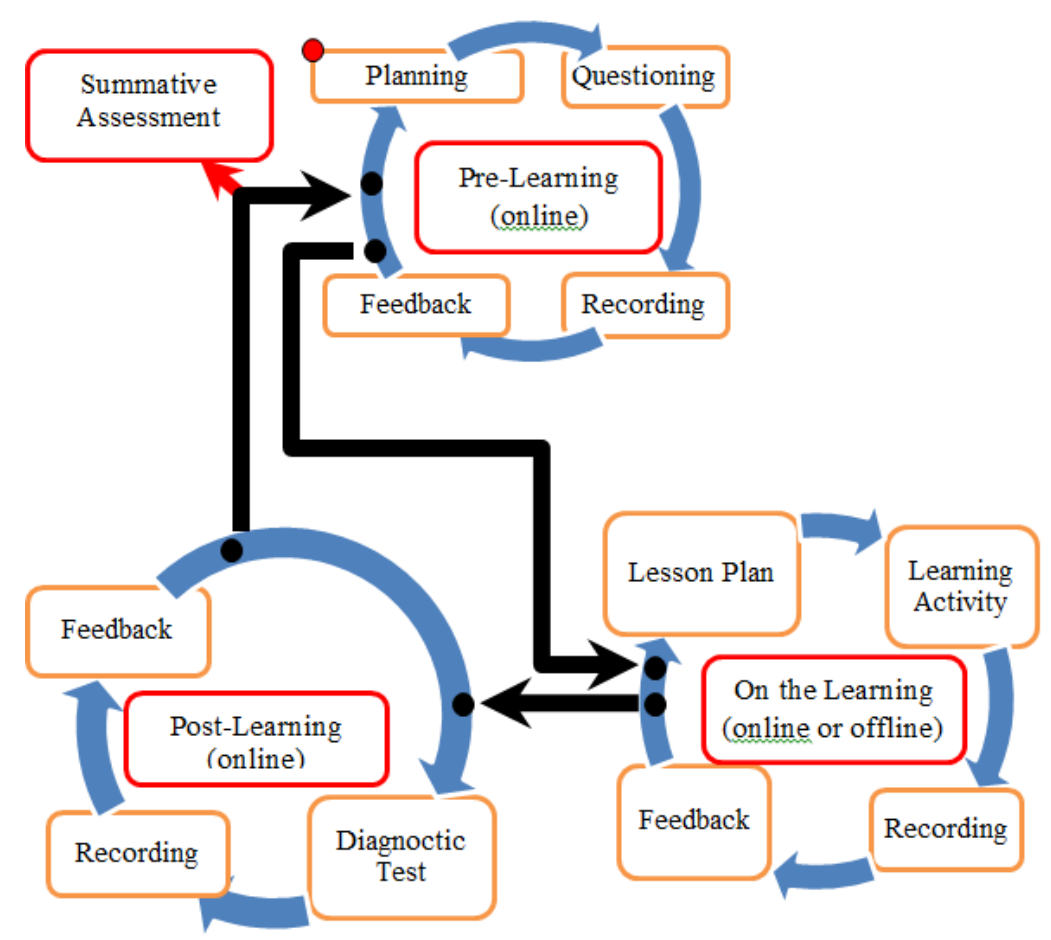

Figure 1. Web-based Formative Assessment Model (Ediyanto, 2014)

\section{A. Drafting}

Reference materials used in the preparation of the formative assessment model is the book Physics for vocational and high school about temperature and heat. Also, I used the other books to support the development of a web-based formative assessment model. The book used is formative assessment and summative assessment, as well as the use of web-based learning.

\section{B. Planning and Developing Initial Product}

In this phase, the instrument has developed a quiz. Manuscript of web-based formative assessment models is a textbook for a description of formative assessment, development instructions, instructions for use for teachers, and instructions for use for students who have previously developed. Quiz developed instruments comprise the post-learning quiz covers material temperature and heat. Post-learning quiz instrument in the form of multiple choice. Questions were developed aiming to determine the extent of students' understanding of the concept. The feedback for each item was designed to help students construct an understanding of the idea individually. As for the teachers as feedback to determine students' achievement of knowledge of the concept.

After the instrument was developed, the media web designed to provide feedback to each student's errors in answering questions. Feedback justification in the form of students' mistakes. After the quiz of post-learning instruments and web formative assessment models have been developed, then to subsequently format with an evaluation by experts and specialists formative assessment materials physics. After revision, followed by limited testing on teachers and students. Then tested the vocational school students' grade $\mathrm{X}$. 
Objective evaluation of this product is to know that feedback has been developed following aspects of formative assessment. The validation was conducted by the expert assessment that already has a suitable qualification. Expert assessment is already experienced at least three years. Evaluate the product on subject matter experts aims to determine how well the problem developed, the suitability of the curriculum, suitability with the material in a product that has been made. Experts who have experienced is a physics lecturer at least three years.

\section{Validating}

The data collection technique used is the technique non-test or questionnaires with a reference scale Likert. The evaluation criteria are the quality of the content, instructional quality, and technical quality. The quality of the content and purpose, namely as to the accuracy, interests, completeness, balance, fairness, and appropriateness to the situation of students. Instructional quality is about providing opportunities to learn, give aid to learning, motivating quality, the flexibility of instructional, quality testing and assessment, and make an impact for students. The technical quality is about legibility, easy to use, display quality, and the quality of the answers.

Questionnaires were developed, namely, questionnaires instrument of post-learning quizzes, and questionnaire web formative assessment models. Experts, teachers, and students validate the Web-based formative assessment models. The assessment results were analyzed by using percentages. The formula used is as follows (Sudjana, 2011: 109).

Data analysis technique

$$
\begin{aligned}
& p=\frac{\sum x}{\sum x_{i}} \times 100 \% \\
& \text { information: } \\
& \mathrm{p} \quad \text { : percentage } \\
& \sum x: \text { Total score of respondents } \\
& \sum x_{i}: \text { Total score of ideal }
\end{aligned}
$$

\section{Revision}

Decision-making revision of textbooks, used levels of qualification with the following criteria.

$$
\begin{aligned}
& 80 \% \leq p \leq 100 \% \text {, Decent and does not need revision } \\
& 60 \% \leq p<80 \% \text {, It is feasible and does not need revision } \\
& 50 \% \leq p<60 \% \text {, Less worthy and need revision } \\
& p<50 \% \text {, Unfit and had revision total }
\end{aligned}
$$


Learning an instrument can be considered worthy and ready to be tested if the final score obtained more than $60 \%$ and revision of media attention to suggestions and comments from the validator. If the final score obtained below $50 \%$ then the media should be revised total by taking into account suggestions and comments from the validator.

\section{E. Trial in the Field}

The population in this trial is a class vocational school grade $\mathrm{X}$ in Malang city. Samples were taken randomly in one class as a group. The number of students in the first class of 40 students. Students included in the study subjects if you follow all the circuits of each treatment. Physics lesson hours per week is 2 x 40 minutes.

There are two types of data collected in this study that treatment test scores and data observation sheets. Implementing data collection in this study were teachers. For the successful implementation of this study, researchers gave an introduction about the web-based formative assessment model and feedback tests and an explanation of the research. As an observer, researcher assisted an observer to observe classroom activities. Explained to the students about the operation Moodle, Implementation of the data collection was conducted over five times the learning. A meeting was used to introduce Moodle and the manner of service. Then, three sessions will be used for the implementation of data collection and the last meeting summative tests. After the application of data collection has been done, the results of the quiz of post-learning, students must be analyzed descriptively.

\section{Result and Discussion}

Problem quiz post-learning developed based on the indicators of achievement of competencies, which later developed into an indicator item. The number of questions that were designed as many as 42 questions divided into three meetings. The first meeting of the temperature and the thermometer, the second meeting of the heat, and the third meeting of Black Principle. Tables 1, 2 , and 3 show the distribution of competence achievement indicators and indicators items. 
Table 1.

Mapping Competency Achievement Indicators and Indicators Item Problem of Temperature and Thermometers

\begin{tabular}{|c|c|c|}
\hline $\begin{array}{l}\text { Indicators of } \\
\text { Competency } \\
\text { Achievement } \\
\end{array}$ & Indicator Problem Items & $\mathbf{N}$ \\
\hline \multirow{3}{*}{$\begin{array}{l}\text { Convert a thermometer } \\
\text { scale to another scale } \\
\text { thermometer }\end{array}$} & $\begin{array}{l}\text { Convert Celsius thermometer scale to the level of the } \\
\text { thermometer X }\end{array}$ & 1 \\
\hline & $\begin{array}{l}\text { Convert Fahrenheit thermometer scale to the Celsius } \\
\text { thermometer scale }\end{array}$ & 2 \\
\hline & $\begin{array}{l}\text { Convert Kelvin scale of the thermometer into the thermometer } \\
\text { scale Reaumur }\end{array}$ & 1 \\
\hline \multirow{2}{*}{$\begin{array}{l}\text { Explaining the concept } \\
\text { of temperature }\end{array}$} & Choose the correct statement about the temperature & 1 \\
\hline & $\begin{array}{l}\text { Explaining the energy of the object when the temperature is } \\
\text { raised }\end{array}$ & 1 \\
\hline $\begin{array}{l}\text { Analyzing the use of a } \\
\text { measurement data } \\
\text { thermometer }\end{array}$ & $\begin{array}{l}\text { Analyzing large fluid temperature with a thermometer } \mathrm{z} \text { if the } \\
\text { data presented fluid temperature on the thermometer } \mathrm{x} \text { and } \mathrm{y} \text {. }\end{array}$ & 2 \\
\hline
\end{tabular}

Table 2.

Mapping Competency Achievement Indicators and Indicators Item Problem of Heat

\section{Indicators of Competency} Achievement

Indicator Problem Items $\quad$ N

Mention the 3 phase transition that releases or absorbs heat

Describing the effects of heat to change the form of an object

Describing the effects of the specific heat and temperature changes in the form of objects

Determine the temperature of objects when the objects change form

Analyze the effect of heat on the characteristics of objects

Applying the equations relating to heat

Choosing a form of change which releases or absorbs heat properly

Explains that heat if given to change the structure is influenced by the mass and heat melting/freezing then no change in body temperature during a change of form Explain the relationship of temperature changes with the specific heat of an object if the data presented neighbor mass

Determine the heat of the object when it changes form

Analyze the impact of the specific heat of the heat given, if given the data

Calculate the heat capacity of copper if the copper absorbs presented data on the masses, the initial temperature, the final temperature, and heat

Calculate the amount of heat required, if known data about the object's mass, temperature changes and the specific heat of objects

Calculate the final temperature of heating, if presented data on the masses, the initial temperature, and heat 


\begin{tabular}{lll}
\hline \multicolumn{1}{c}{$\begin{array}{c}\text { Indicators of } \\
\text { Competency } \\
\text { Achievement }\end{array}$} & \multicolumn{1}{c}{ Indicator Problem Items } & N \\
\hline $\begin{array}{l}\text { Analyzing the } \\
\text { relationship between } \\
\text { heat, mass, specific heat, } \\
\text { heat capacity, and } \\
\text { temperature changes }\end{array}$ & $\begin{array}{l}\text { Analyzing the heat capacity of an object from several data } \\
\text { Analyzing the specific heat of a substance from several data on } \\
\text { changes in temperature, mass, and heat of a substance } \\
\text { Analyzing the temperature changes that occur from several } \\
\text { data and images }\end{array}$ & 2 \\
$\begin{array}{l}\text { Analyzing the mass relationships, changes in temperature, and } \\
\text { heat }\end{array}$ & 1 \\
$\begin{array}{l}\text { Calculating the effect of } \\
\text { heat on the characteristics } \\
\text { of objects }\end{array}$ & $\begin{array}{l}\text { Calcuting the amount of heat that must be given in the form } \\
\text { data graph }\end{array}$ & 2 \\
$\begin{array}{l}\text { Analyzing the process of } \\
\text { changing states of matter }\end{array}$ & $\begin{array}{l}\text { Presented two statements regarding the phase transition } \\
\text { process. Participants were asked to examine whether the two } \\
\text { statements relate cause and effect or not. }\end{array}$ & 2 \\
\hline
\end{tabular}

Table 3.

Mapping Competency Achievement Indicators and Indicators Item Problem of Black Principle

\begin{tabular}{|c|c|c|}
\hline $\begin{array}{l}\text { Indicators of } \\
\text { Competence } \\
\text { Achievement }\end{array}$ & Indicator Problem Items & $\mathbf{N}$ \\
\hline $\begin{array}{l}\text { Indicators of } \\
\text { Competency } \\
\text { Achievement } \\
\text { Explaining } \\
\text { temperature of the } \\
\text { mixture is based on the } \\
\text { principle of Black } \\
\text { Principle }\end{array}$ & $\begin{array}{l}\text { Clarifying the definition of the temperature of the } \\
\text { mixture/temperature equilibrium }\end{array}$ & $\mathrm{N}$ \\
\hline $\begin{array}{l}\text { Black Principle cites the } \\
\text { example application in }\end{array}$ & $\begin{array}{l}\text { Choosing a statement by examples of the implementation of } \\
\text { Black Principle in everyday life }\end{array}$ & 1 \\
\hline $\begin{array}{l}\text { everyday life } \\
\text { Explaining the process of } \\
\text { heat absorbed and } \\
\text { disposed of in Black } \\
\text { Principle }\end{array}$ & Choosing a statement in accordance with the principles Black & 1 \\
\hline $\begin{array}{l}\text { Applying the Principle of } \\
\text { Black in solving physics }\end{array}$ & $\begin{array}{l}\text { Determine the correct statement of the case given } \\
\text { Calculating the specific heat of a metal using black Azas, if } \\
\text { presented some data about the mass, temperature changes, the } \\
\text { specific heat of water and glasses }\end{array}$ & $\begin{array}{l}1 \\
1\end{array}$ \\
\hline & $\begin{array}{l}\text { Calculate the temperature of the mixture using black Azas, if } \\
\text { presented data on mass, temperature and the specific heat of a } \\
\text { substance }\end{array}$ & 1 \\
\hline & $\begin{array}{l}\text { Calculate the temperature change, if presented data on heat, } \\
\text { mass and specific heat ratio of aluminum and iron }\end{array}$ & 1 \\
\hline $\begin{array}{l}\text { Calculate the final } \\
\text { temperature of the }\end{array}$ & $\begin{array}{l}\text { Calculate the equilibrium temperature when two bodies are } \\
\text { mixed }\end{array}$ & 2 \\
\hline
\end{tabular}




\begin{tabular}{lll}
\hline $\begin{array}{l}\text { Indicators of } \\
\text { Competence } \\
\text { Achievement }\end{array}$ & \multicolumn{1}{c}{ Indicator Problem Items } \\
\hline $\begin{array}{l}\text { mixture in mixing the } \\
\text { two substances } \\
\text { regardless the } \\
\text { conditions container }\end{array}$ & $\begin{array}{l}\text { Determining the temperature rise that occurs, if the matter is } \\
\text { presented in the form of the potential energy of a waterfall that } \\
\text { turns into heat energy that can be used to raise the temperature }\end{array}$ \\
$\begin{array}{l}\text { Linking the concept of } \\
\text { handover heat with } \\
\text { another form of energy } \\
\text { concepts }\end{array}$ \\
$\begin{array}{l}\text { Evaluating } \\
\text { Principle in solving } \\
\text { physics }\end{array}$ & $\begin{array}{l}\text { Calculate the mass of water to evaporate, if the matter is } \\
\text { presented in the form of linkages between electrical energy and } \\
\text { used for a specified time interval. }\end{array}$ \\
& $\begin{array}{l}\text { Predicting the temperature of the mixture when the A and C } \\
\text { were mixed using black Azas amount of data about the three } \\
\text { objects of different temperatures when A and C are mixed } \\
\text { acquired a specific equilibrium temperature, while B and C are } \\
\text { mixed acquired a particular temperature of equilibrium }\end{array}$ & 1 \\
\hline
\end{tabular}

The presentation was given at random questions because the program Web-based can have features that can present a problem at random. One question number consisted of one or more items, so there is a possibility the students get problems that are not the same when repeating to answer the question. Among the students with other students also have the chance to understand problems that are not the same. The presentation of the questions was packaged in a post-learning quiz.

Post-learning quiz is a quiz conducted after learning in the classroom. This quiz is part of the post-learning cycle contain multiple-choice questions related to materials that have been studied previously. Students working on this quiz will determine the level of understanding of the concept. For students who have not reached the level of understanding the concept, then there will be feedback to improve student conceptual understanding. Feedback was given after a student quiz after learning. After the quiz, students will determine the extent of students' conceptual understanding after learning in the classroom. Post-learning form of matter in the quiz is multiple choice with five possible answers. Table 4 presents an example of a quiz question of post-learning. 
Table 4.

Questions sample of post-learning quiz

\begin{tabular}{|c|c|}
\hline Problem & Feedback \\
\hline \multicolumn{2}{|c|}{ Analyze the effect of the specific heat of the heat given, if given the data } \\
\hline $\begin{array}{l}\text { Substance A and B are the same mass. To raise the } \\
\text { same temperature, a substance requires more heat } \\
\text { than the heat needed substances B. This means... } \\
\text { A. A substance heat faster } \\
\text { B. Specific heat of substances <substance B } \\
\text { C. Specific heat of substances A>B substances } \\
\text { D. A heat capacity substances < substance B } \\
\text { E. A substance evaporates more quickly. } \\
\text { Answer Key: C } \\
\text { Cognitive realm: C4 }\end{array}$ & $\begin{array}{l}\text { Heat is needed to change the } \\
\text { temperature of a substance depends on } \\
\text { the object's mass and heat type. In two } \\
\text { substances that same mass, then the heat } \\
\text { is proportional to the magnitude of the } \\
\text { specific heat. } \\
\text { A substance of the matter known to } \\
\text { require more heat so that it can be } \\
\text { inferred calorific types of substances } \\
\text { A> B substances }\end{array}$ \\
\hline $\begin{array}{l}\text { Object A and B the same mass when given the same } \\
\text { amount of heat that turns the temperature rise A } \\
\text { higher than the temperature increase B. The } \\
\text { following statement describes the condition is... } \\
\text { A. Specific heat B greater than the specific heat A } \\
\text { B. Density A smaller than the density of B } \\
\text { C. Heat capacity B lower than the heat capacity A } \\
\text { D. Specific heat B smaller than the specific heat A } \\
\text { E. Density A higher than the density of B } \\
\text { Answer Key: A } \\
\text { Cognitive realm: C4 }\end{array}$ & $\begin{array}{l}\text { Heat is needed to change the } \\
\text { temperature of a substance depends on } \\
\text { the object's mass and heat type. In two } \\
\text { substances that same mass, then the heat } \\
\text { is proportional to the magnitude of the } \\
\text { specific heat. } \\
\text { A substance of the matter known to } \\
\text { the higher temperature rise, so that we } \\
\text { can conclude the specific heat of } \\
\text { substances A < substance B }\end{array}$ \\
\hline
\end{tabular}

The instruments in the post-learning cycle are in the form of multiple-choice questions with five possible answers. Each number consists of several questions about the equivalent level of difficulty. About the post-learning instrument that developed as a component of product development is analyzed through the content validation results (Content validity) derived from scores on the questionnaire validation to the validator. Questionnaire validation consisted of a questionnaire assessment using a reference scale Likert, Questionnaire assessment contains the assessment criteria, namely: 1) the suitability of items with indicators, 2) the accuracy of cognitive domains with items, 3) the accuracy of the feedback, 4) feedback can provide an understanding of students concepts, 5) equality level of difficulty about, and 6 ) sentence about not cause a double perception. 
Table 5.

Validation Problem Quiz of Post-learning

\begin{tabular}{|c|c|c|c|c|c|c|c|c|c|}
\hline \multirow{2}{*}{ Validator } & \multirow{2}{*}{ Matter } & \multicolumn{8}{|c|}{ Problem No. Percentage (in\%) } \\
\hline & & 1 & 2 & 3 & 4 & 5 & 6 & 7 & 8 \\
\hline \multirow{3}{*}{1} & $\begin{array}{l}\text { Temperature and } \\
\text { Thermometers }\end{array}$ & 100 & 100 & 83.33 & - & - & - & - & - \\
\hline & Heat & 100 & 100 & 100 & 75 & 100 & 95.83 & 79.17 & 100 \\
\hline & Black Principle & 100 & 100 & 91.67 & 91.67 & 100 & 95.83 & - & - \\
\hline \multirow{3}{*}{2} & $\begin{array}{l}\text { Temperature and } \\
\text { Thermometers }\end{array}$ & 100 & 91.67 & 100 & - & 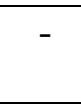 & 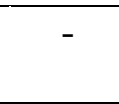 & 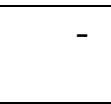 & - \\
\hline & Heat & 100 & 100 & 100 & 100 & 100 & 91.67 & 95.83 & 95.83 \\
\hline & Black Principle & 100 & 100 & 100 & 100 & 100 & 91.67 & - & - \\
\hline
\end{tabular}

Based on validation results by experts/validator, it can be analyzed that each question does not require revision. The average percentage is more than $80 \%$ (worth it) except in the matter number 4 and number 7 calorific material. On Question 4, the validator 1 to provide an assessment with the percentage of $75.00 \%$. The revision should be done in a matter of numbers, and four calorific materials are essential to justify answers and feedback. On Question 7 calorific material, the validator 1 provides an assessment by the percentage of $79.17 \%$. The revision should be done in a matter of number 7 calorific material are equalizes the level of difficulty about the extent to analyze.

\section{A. Diagnostic Test Phase}

Question sentences can contain multiple-choice questions, accompanied by five possible answers. There are buttons A, B, C, D, and E should be pressed students when answering the questions. Answer choices appear randomly. After students complete the quiz of post-learning, students can immediately see the results and find out where the problem is. Students can also find an explanation of incorrectly answered. Figure 4 presents the multiple-choice questions on a quiz of post-learning. The items number used in diagnostic tests depending on the scope and depth of the material following the purpose of learning. Example questions presented in Table 4.

\section{B. Recording Phase}

After the students have taken a quiz, students immediately know the results. Students know where mistakes and incomprehension concept. Students will find out in a matter in any number you answered incorrectly. Figure 2 presents the results of the quiz. 


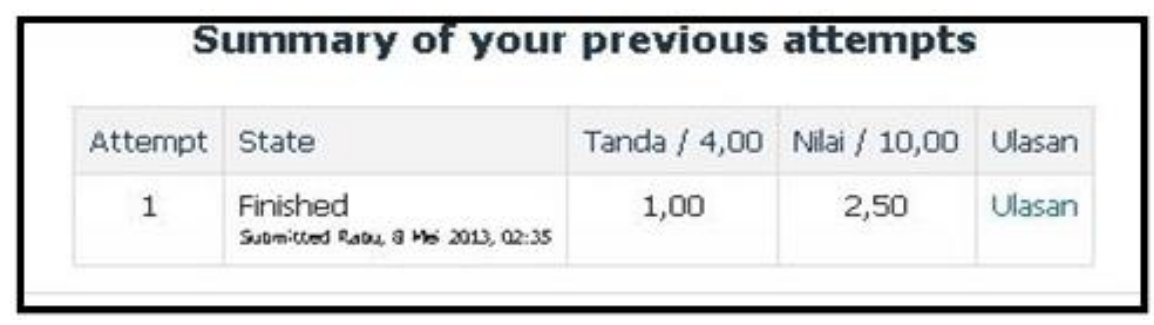

Figure 2. Results of Working Quiz

Records of the results of the quiz can be used by teachers to see the students' understanding of the concept of achievement. The teacher can see the students who are already taking the quiz, a long time, and when students are working on, as well as the results achieved by students. Teachers can also find out the response of each student on each question so that it can be used as feedback for teachers about the learning success. Figure 2 shows the scene recording the results of the quiz.

\section{Feedback Phase}

Feedback on the quiz of post-learning is almost the same as quiz pre-learning (Ediyanto,2016). Feedback on the quiz of post-learning gives the correct answers and discussion. Feedback on the quiz of post-learning is given for the student that answers correctly or incorrectly. Based on the record and this feedback, teachers can map the students' ability and can design an improvement program for students who cannot reach an understanding of the concept of competence and can create enrichment program for theirs.

Table 6.

Records Quiz Results of Post-learning

\begin{tabular}{ccccccc}
\hline \multicolumn{2}{c}{ Quis1 } & \multicolumn{2}{c}{ Quiz 2 } & \multicolumn{2}{c}{ Quis3 } \\
\cline { 2 - 7 } grade & freq & grade & freq & grade & freq \\
\hline $0: 00$ & 0 & $5: 00$ & 5 & $3: 33$ & 4 \\
$3: 33$ & 3 & $6: 25$ & 8 & $5: 00$ & 11 \\
6.67 & 14 & $7: 50$ & 16 & 6.67 & 14 \\
$10: 00$ & 23 & 8.75 & 10 & $8: 33$ & 10 \\
- & - & $10: 00$ & 1 & $10: 00$ & 1 \\
$* 8: 33$ & 40 & $* 7: 31$ & 40 & $* 6: 38$ & 40 \\
\hline
\end{tabular}

* average value

Formative assessment test carried out after online learning, Formative assessment tests of postlearning a quiz called the diagnostic tests. The timing of the test product is five weeks. At the first meeting conducted the introduction of assessment models and the provision of the first assignment. The second meeting of the chapter entry temperature and a thermometer, heat the chapter entered the third meeting, the fourth meeting of the chapter principle Black. At the end of the session, 
summative tests were done to the students about the temperature and heat. Description Data from the summative test results contained in such statistical tables Table 7.

Table 7.

Data Summative Student Test Results

\begin{tabular}{rlc}
\hline No. & statistical & Value \\
\hline 1 & $\mathrm{~N}$ & 40 \\
2 & $\mathrm{X}$ & 81.47 \\
3 & $\mathrm{~s} 2$ & 10,366 \\
4 & $\mathrm{~S}$ & 107444 \\
5 & Nmin & 58.82 \\
6 & Nmaks & 100.00 \\
\hline
\end{tabular}

Noted:

$\mathrm{n} \quad=$ The amount of data

$\mathrm{x} \quad=$ The average value of the summative test students

$\mathrm{S} \quad=$ variant

s2 = Standard deviation

Nmin = Minimum value

Nmaks = Maximum value

The average student diagnostic test results show that some students still do not understand the concept correctly. With feedback in this post-learning quiz, students can reflect and strengthen the concept that has been achieved in learning.

The results showed that students who attended formative assessments have a good understanding of the concept. The value of the summative assessment of students tends to be high at 81.47 , and the highest score is 100 . However, there is still a student with a value of 58.82 , making it a necessary evaluation of the execution post-learning cycle or research explicitly done to students who do not go beyond competence.

\section{Conclusion}

\section{A. Revised of Product}

Formative assessment can provide feedback to teachers and students as a basis for improving the learning process and conducting remedial programs for students in education. The end product of this research is the implementation of the post-learning cycle, a web-based formative assessment model in physics learning materials, and heat temperature for vocational school students grade X. The product can be developed for use at levels of students and different materials. The products designed have been revised based on the results of the content validation by the validator and limited testing. Based on quantitative data analysis, data validation test results, and product quality testing has shown that the resulting product is excellent and able to provide appropriate feedback 
to students' needs in the shortest time. Relevant feedback to students' needs in a short time following the model of formative assessment. In addition, the products developed have been able to improve students' understanding of the concept.

Products in terms of providing feedback have been good for being able to provide feedback quickly, i.e., immediately after students have completed solving problems. Products in terms of the ability to improve students' understanding of a concept already well. Quick feedback can enhance students' understanding of the concept according to the study. The products that developed in the current study, in terms of the instrument quiz, which is a component of the product development, have been good, for a given problem is correct in concept.

The web-based formative assessment model has advantages and disadvantages. Excess in the formative assessment system is (1) can provide feedback in a short time after the students have finished exercises. (2) enable to indicates where students' mistakes and give the discussion incorrectly answered by students, (3) assist the teachers in implementing formative assessment, (4) help students in improving the understanding of the concept, and (5) provide a report to the teacher about the increasing understanding of the concept of students. Disadvantages of the system of formative assessment computer-aided developed (1) limited to the material temperature and heat, (2) the Indonesian language used is still not perfect, there is still a mixture of English, (3) only been tested in one class, and (4) there has been no remedial material. The second deficiency can be overcome by using English only.

The trials in field steps provided a clear picture that the web-based formative assessment model can increase students' understanding of the concept. From the test results of understanding the concept of student learning with the web-based formative assessment model has an average of 81.47. However, this has not been done in limited testing and field trials, and the trials are still using Indonesian.

\section{B. Future Direction}

Suggestions that can be put forward after doing this research are to conduct further research on a web-based formative assessment model that has been developed. The product needs to be repeated and includes a more significant number of students who can be seen to be more about the quality. The quality that improves is the quiz of post-learning, feedback, and remedial materials provided by the product development so that the resulting product is more can be utilized by teachers and students when doing the learning. Manual for teachers to ask students to take the quiz of post-learning repeatedly. It is intended to understand the concept of fault location. For teachers to ask students to read the feedback given. Further research will be conducted on material and 
other levels of education as well as making improvements to the web-based formative assessment model.).

\section{References}

[1] Arends, I., R. (2008). Learning to Teach. (H. P. Soetjipto \& S. N. Soetjipto, Trans). Yogyakarta: Pustaka Belajar.

[2] Arifin, Z. (2009). Evaluasi Pembelajaran. Bandung: PT Remaja Rosdakarya.

[3] Borg, W., R. \& Gall, M., D. (1983). Educational Re ssearch. An Introduction (4th ed.). New York: Longman Inc.

[4] Ediyanto. (2016). Siklus Prapembelajaran Model Penilaian Formatif Web-Based Pada Pembelajaran Fisika Materi Suhu dan Kalor untuk Siswa SMK Kelas X. Jurnal Pendidikan Fisika Indonesia, 12(2), 126-136. doi:http://dx.doi.org/10.15294/jpfi.v12i2.5906

[5] Ediyanto. (2014). Development of Web-Based Formative Assessment Model to Enhance Physics Concepts of Students. Jurnal Pendidikan Sains, 2(2), 63-75.

[6] Etkina, E. (2002). Formative and Summative Assessment in a Physics Class: Time to Change. Perc Publishing: 3.,

[7] Fakcharoenphol, W., Potter, E., \& Stelzer, T. (2011). What students learn when studying physics practice exam problems. Physical Review Special Topics-Physics Education Research, 7(1), 010107.

[8] Irons, A. (2008). Enhancing Learning Through Formative Assessment and Feedback. Oxon: Routledge.

[9] Lipnevich, A., \& Smith, J. (2009). Effects of differential feedback on students' examination performance. Journal of Experimental Psychology, 15(4), 319-333.

[10] McAlpine, M. (2002). Principles of Assessment. University of Luton: Computer Assisted Assessment Centre.

[11] Otsuka, J., \& Vieira da Rocha, H. (2007). Online assessment: supporting the formative assessment of collaborative learning activities. In IADIA Conference WWW/Internet 2007 (pp. 35-42).

[12] Sudjana, N. (2011). Penilaian Hasil Proses Belajar Mengajar. Bandung: PT Remaja Rosdakarya.

[13] Stull, J., Varnum, S. J., Ducette, J., \& Schiller, J. (2011). The Many Faces of Formative Assessment. International Journal of Teaching and Learning in Higher Education, 23(1), 3039.

[14] Wagner, C. \& Vaterlaus, A. (2011). Promoting Formative Assessment in High School Teaching of Physics. Latin America Journal of Physics Education, 6, 410-415. 